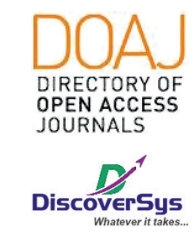

Published by DiscoverSys

\title{
Gambaran pengetahuan, sikap, dan perilaku tentang vaginal hygiene terhadap kejadian keputihan patologis pada siswi kelas 1 di SMA Negeri 1 Denpasar periode Juli 2018
}

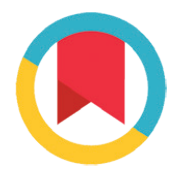

CrossMark

\author{
Ida Ayu Cintya Pradnyandari, ${ }^{1 *}$ I Gede Ngurah Harry Wijaya Surya, ${ }^{2}$ Made Bagus Dwi Aryana ${ }^{2}$
}

\section{ABSTRACT}

Introduction: Leucorrhea was a prolonged problem that has been experienced by women, especially teenagers. Teenagers are part of a population that are at risk. Pathological leucorrhea which is not prevented and handled properly can cause various disease and have a fatal end. This research aimed to know how were the knowledge, attitudes, and behavior of vaginal hygiene towards pathological leucorrhea phenomenon on first grade female students in 1 Senior High School of Denpasar City.

Method: This research was a descriptive study with cross-sectional method. The research subject was 106 first grade female students in 1
Senior High School of Denpasar City. The data were collected on $26^{\text {th }}$ of July 2018. This research used primary data from the questionnaire that had been filled out.

Result: The results showed that the level of knowledge about vaginal hygiene was $99,9 \%$ good and 0,1\% bad. The level of attitudes about vaginal hygiene was $100 \%$ good. The level of behavior about vaginal hygiene was $98,2 \%$ good and $1,8 \%$ bad.

Conclusion: Most of the student in Senior High School 1 Denpasar have a good level of knowledge, attitude, and behavior towards vaginal hygiene.

Keywords: knowledge, attitudes, behavior, vaginal hygiene.

Cite This Article: Pradnyandari, I.A.C., Surya, I.G.N.H.W., Aryana, M.B.D. 2019. Gambaran pengetahuan, sikap, dan perilaku tentang vaginal hygiene terhadap kejadian keputihan patologis pada siswi kelas 1 di SMA Negeri 1 Denpasar periode Juli 2018. Intisari Sains Medis 10(1): 88-94. DOl: 10.1556/ism.v10i1.357

\section{ABSTRAK}

Latar Belakang: Masalah keputihan adalah masalah sejak lama yang telah dialami oleh wanita khususnya remaja. Remaja adalah bagian dari populasi yang beresiko. Keputihan patologis yang tidak dicegah dan ditangani dengan baik dapat menimbulkan berbagai penyakit dan berujung fatal. Penelitian ini bertujuan untuk mengetahui bagaimana pengetahuan, sikap, dan perilaku tentang vaginal hygiene terhadap kejadian keputihan patologis pada siswi kelas 1 di SMA Negeri 1 Denpasar. Metode: Penelitian ini merupakan penelitian deskriptif dengan metode cross- sectional. Subjek penelitian adalah 106 siswi kelas 1 di SMA Negeri 1 Denpasar yang telah menstruasi. Pengambilan data Kedokteran dan Profesi Dokter Fakultas Kedokteran, Universitas Udayana

${ }^{2}$ Departemen Obstetri dan Ginekologi Fakultas Kedokteran Universitas Udayana/RSUP Sanglah

*Corresponding:

Ida Ayu Cintya Pradnyandari, Program Studi Sarjana Kedokteran dan Profesi Dokter, Fakultas Kedokteran, Universitas Udayana cintyapradnyandari@gmail.com

Received: 2018-11-13 Accepted: 2018-11-22 Published: 2019-04-01

Kata Kunci: pengetahuan, sikap, perilaku, vaginal hygiene. 10.1556/ism.v10i1.357

\section{PENDAHULUAN}

Masa remaja adalah masa peralihan dari anak menuju dewasa. Proses untuk mencapai kedewasaan biasanya ditandai dengan pubertas yang berhubungan erat dengan perubahan aspek fisik dan psikis. Perubahan aspek fisik adalah yang paling dilakukan pada tanggal 26 Juli 2018. Data penelitian adalah data primer dari pengisian kuesioner.

Hasil: Penelitian ini menunjukkan tingkat pengetahuan tentang vaginal hygiene didapatkan data sebesar $99,9 \%$ baik dan 0,1\% buruk. Tingkat sikap tentang vaginal hygiene didapatkan data sebesar $100 \%$ baik. Tingkat perilaku tentang vaginal hygiene didapatkan data sebesar $98,2 \%$ baik dan $1,8 \%$ buruk.

Simpulan: Sebagian besar siswa SMA Negeri 1 Denpasar memiliki tingkat pengetahuan, sikap, dan prilaku yang baik terhadap vaginal hygiene.

Cite Pasal Ini: Pradnyandari, I.A.C., Surya, I.G.N.H.W., Aryana, M.B.D. 2019. Gambaran pengetahuan, sikap, dan perilaku tentang vaginal hygiene terhadap kejadian keputihan patologis pada siswi kelas 1 di SMA Negeri 1 Denpasar periode Juli 2018. Intisari Sains Medis 10(1): 88-94. D0I:

penting karena berlangsung dengan cepat, drastis dan bermuara pada organ reproduksi. Organ reproduksi memerlukan perawatan khusus. Pengetahuan dan perawatan yang baik merupakan faktor penentu dalam menjaga kesehatan reproduksi. 
Kesehatan reproduksi remaja adalah suatu kondisi sehat yang menyangkut sistem, fungsi dan proses reproduksi yang dimiliki oleh remaja. ${ }^{1}$ Salah satu masalah yang sering dialami oleh remaja khususnya wanita adalah keputihan. Remaja adalah bagian dari populasi yang beresiko dan harus mendapatkan pehatian khusus. ${ }^{2}$

Masalah organ reproduksi pada remaja ini sering muncul di negara - negara berkembang seperti Indonesia. Berdasarkan data penelitian kesehatan reproduksi wanita didapatkan $75 \%$ wanita di dunia pernah mengalami keputihan setidaknya satu kali dalam hidupnya. Di Eropa angka kejadian keputihan hanya $25 \%$, sedangkan di Indonesia sendiri didapatkan 50\% wanita mengalami keputihan. Angka kejadian keputihan di Indonesia terus meningkat tiap tahunnya hingga mencapai $70 \%{ }^{3}$

Keputihan (leucorrhea, vaginal discharge) adalah keluarnya sekret atau cairan selain darah yang berlebihan dari liang vagina dengan variasi bau, konsistensi, dan warna. Keputihan dapat terjadi secara normal (fisiologis) maupun abnormal atau penyakit (patologis). Keputihan yang normal tidak berwarna atau bening, tidak berbau, tidak berlebihan dan tidak menimbulan keluhan. ${ }^{4}$

Faktor pencetus keputihan dapat dibagi menjadi dua yaitu faktor infeksi dan faktor non-infeksi. Faktor infeksi dapat disebabkan oleh bakteri, jamur, parasit, ataupun virus. Sedangkan faktor non-infeksi disebabkan oleh kurang bersihnya daerah vagina, masuknya benda asing, jarang mengganti celana dalam maupun pembalut saat menstruasi, perawatan saat menstruasi yang kurang benar, dan penggunaan celana yang tidak menyerap keringat. ${ }^{2}$ Keputihan patologis yang tidak ditangani dengan baik akan dapat menimbulkan berbagai penyakit dan akan berujung fatal yaitu kemandulan, kehamilan diluar uterus, dan sebagai gejala awal kanker serviks. ${ }^{5}$

Remaja umumnya tidak memiliki cukup informasi mengenai kesehatan reproduksi dan memiliki kesalahan persepsi mengenai keseha$\tan$ reproduksi. Minimnya pemahaman yang dimiliki oleh remaja disebabkan oleh kurangnya ketersediaan akses untuk mendapatkan informasi mengenai kesehatan reproduksi. Hal ini menjadi pencetus semakin banyaknya kejadian keputihan pada remaja. Terbukti dari banyaknya penelitian yang menyatakan rendahnya tingkat pengetahuan menjaga kebersihan organ genitalia pada remaja putri. $^{6}$

\section{METODE}

Jenis penelitian yang digunakan pada penelitian ini adalah deskriptif dengan metode potong lintang (cross-sectional). Penelitian ini dilakukan di SMA Negeri 1 Dnepasar pada tanggal 26 Agustus 2018.
Sampel pada penelitian ini adalah populasi terjangkau yang memenuhi kriteria inklusi dan ekslusi. Kriteria inklusi pada penelitian ini adalah siswi kelas 1 di SMA Negeri 1 Denpasar yang bersedia mengisi kuesioner, sedangkan kriteria eklusi pada penelitian ini adalah siswi kelas 1 di SMA Negeri 1 Denpasar yang tidak mengisi kuesioner secara lengkap. Berdasarkan rumus besar sampel yang telah digunakan, didapatkan jumlah sampel minimum pada pnelitian ini adalah 96 orang. Untuk mengantisipasi bias maka jumlah sampel ditambah $10 \%$ dari besar sampel minimum, sehingga total sampel yang digunakan pada penelitian ini adalah 106 orang. Data yang dikumpulkan adalah data primer, yaitu kuesioner yang diisi langsung oleh responden. Teknik pengambilan sampel dengan simple random sampling. Data yang terkumpul akan diolah dengan menggunakan SPSS versi 21.0 dan dianalisis deskriptif. Hasilnya akan ditampilkan dalam bentuk table frekuensi.

\section{HASIL DAN PEMBAHASAN}

Secara umum pengetahuan, sikap, dan perilaku tantang vaginal hygiene terhadap kejadian keputihan patologis berdasarkan hasil penelitian adalah baik. 105 dari 106 responden (99,9\%) memiliki pengetahuan yang baik dan 1 responden memiliki pengetahuan yang buruk $(0,1 \%)$ mengenai vaginal hygiene terhadap kejadian keputihan. 106 respoden (100\%) pada penelitian ini memiliki sikap yang baik. 104 dari 106 responden (98,2\%) memiliki perilaku yang baik dan 2 responden memiliki perilaku yang buruk (1,8\%) (Gambar 1$)$.

Beberapa faktor dapat mempengaruhi hasil dari penelitian yaitu diantaranya faktor usia, pendidikan dan lingkungan. Usia tertinggi responden adalah 17 tahun dan usia terendah 15 tahun. Remaja dari segi usia dapat dibedakan menjadi remaja awal (10-13 tahun), remaja menengah (14-16 tahun) dan remaja akhir (17-20 tahun). ${ }^{7}$ Semakin dewasa usia seseorang tingkat pengetahuan akan semakin bertambah, semakin mudah menerima informasi, menjadi lebih matang dalam bepikir dan bertindak.

Selain faktor usia, faktor lingkungan juga dapat mempengaruhi hasil dari penelitian. Faktor lingkungan yang dimaksut adalah lingkungan rumah dan lingkungan sosial. Informasi mengenai vaginal hygiene umumnya juga dapat diberikan oleh orangtua, saudara, maupun kerabat terdekat. Lingkungan sosial juga berperan dalam memberikan informasi pada remaja. Pemikiran dan perilaku remaja cenderung berubah-ubah mengikuti teman sekitarnya. Hal tersebut karena remaja merasa lebih dekat dengan teman sebayanya, merasa ingin bebas, dan mulai mencari identitas diri. Selain itu remaja juga merupakan masa yang mudah terpapar 


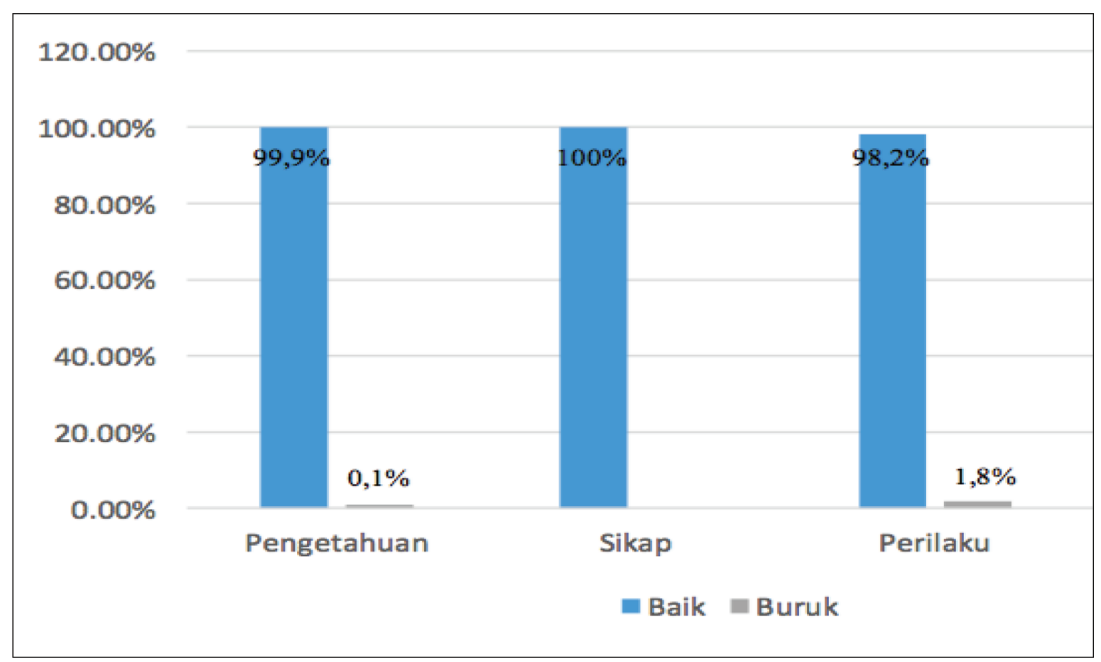

Gambar 1 Tingkat Pengetahuan, Sikap, dan Perilaku tentang Vaginal Hygiene terhadap Kejadian Keputihan Patologis pada Siswi Kelas I di SMA Negeri 1 Denpasar mode atau tren, sehingga apapun yang dilakukan oleh lingkungan sosialnya, remaja cenderung akan mengikuti hal tersebut.

\section{Pengetahuan tentang Vaginal Hygiene dan Keputihan}

Pada penelitian ini secara umum responden memiliki pengetahuan yang baik. 95 orang dari 106 responden $(89,6 \%)$ mengetahui cara membasuh vagina yang benar. 106 responden (100\%) mengetahui keputihan dapat terjadi secara normal (fisiologis) maupun abnormal (patologis). 81 orang dari 106 responden $(76,4 \%)$ dapat mengindentifikasi penyebab keputihan, dan 66 orang dari $106(63,3 \%)$ responden mengetahui gejala keputihan patologis. Hasil penelitian mengenai pengetahuan dapat dilihat pada tabel 1 . 66 orang dari $106(63,3 \%)$ responden mengetahui gejala keputihan patologis. Hasil penelitian mengenai pengetahuan dapat dilihat pada tabel 1 .

Tabel 1 Tipe Pertanyaan dan Tingkat Pengetahuan Vaginal Hygiene

\begin{tabular}{|c|c|c|c|c|}
\hline \multirow[b]{3}{*}{ No } & \multirow[b]{3}{*}{ Tipe Pertanyaan } & \multirow[b]{3}{*}{ Nomer dan konten } & \multicolumn{2}{|c|}{ Hasil } \\
\hline & & & Salah & Benar \\
\hline & & & $\%$ & $\%$ \\
\hline \multirow[t]{6}{*}{1} & \multirow[t]{6}{*}{ Pengetahuan membasuh vagina } & Pengetahuan membasuh & $11(10,4)$ & $95(89,6)$ \\
\hline & & Kebersihan tangan & $1(0,9)$ & $105(99,1)$ \\
\hline & & Pengetahuan mencukur rambut pubis & $34(32,1)$ & $72(67,9)$ \\
\hline & & Cara mebasuh vagina & $8(7,5)$ & $98(92,5)$ \\
\hline & & Alat yang digunakan untuk mebasuh vagina & $26(24,5)$ & $80(75,5)$ \\
\hline & & Kegiatan membasuh vagina paska buang air kecil & $13(12,3)$ & $93(87,7)$ \\
\hline \multirow[t]{5}{*}{2} & \multirow[t]{5}{*}{ Tidakan pencegahan keputihan } & Pemiliham pakaian dalam & $31(29,2)$ & $75(70,8)$ \\
\hline & & Pengetahuan bahan pakaian dalam & $18(17)$ & $88(83)$ \\
\hline & & Pengetahuan perbandingan bahan pakaian dalam & $28(26,4)$ & $78(73,6)$ \\
\hline & & Pengetahuan penggunaan pakaian dalam & $2(1,9)$ & $104(98,1)$ \\
\hline & & Pengetahuan hygiene pakaian dalam & $4(3,8)$ & $102(96,2)$ \\
\hline \multirow[t]{2}{*}{3} & \multirow[t]{2}{*}{ Pengetahuan sabun cuci vagina } & Pengetahuan sabun vagina & $6(5,7)$ & $106(94,3)$ \\
\hline & & Pengetahuan penggunaan antiseptik & $15(14,2)$ & $91(85,8)$ \\
\hline \multirow[t]{9}{*}{4} & \multirow[t]{9}{*}{ Keputihan } & Pengetahuan umum kebersihan vagina & $0(0)$ & $106(100)$ \\
\hline & & Jenis Keputihan & $0(0)$ & $106(100)$ \\
\hline & & Penyebab keputihan & $25(23,6)$ & $81(76,4)$ \\
\hline & & Keputihan normal & $37(34,9)$ & $69(65,1)$ \\
\hline & & Gatal pada keputihan & $59(55,7)$ & $47(44,3)$ \\
\hline & & Keputihan tidak normal & $40(37,7)$ & $66(62,3)$ \\
\hline & & Bau pada keputihan & $54(50,9)$ & $52(49,1)$ \\
\hline & & Infeksi jamur & $8(7,5)$ & $98(92,5)$ \\
\hline & & Cairan anstiseptik dalam keputihan & $14(13,2)$ & $92(86,8)$ \\
\hline \multirow[t]{3}{*}{5} & \multirow[t]{3}{*}{ Pegetahuan penggunaan pakaian dalam } & Bahan pakaian dalam & $11(10,4)$ & $95(89,6)$ \\
\hline & & Pembalut & $4(3,8)$ & $102(96,2)$ \\
\hline & & Pengetahuan penggunaan pakaian dalam & $1(0,9)$ & $105(99,1)$ \\
\hline
\end{tabular}




\begin{tabular}{|c|c|c|c|c|}
\hline \multirow[b]{3}{*}{ No } & \multirow[b]{3}{*}{ Tipe Pertanyaan } & \multirow[b]{3}{*}{ Nomer dan konten } & \multicolumn{2}{|c|}{ Hasil } \\
\hline & & & Salah & Benar \\
\hline & & & $\%$ & $\%$ \\
\hline \multirow[t]{7}{*}{1} & Sikap dalam membasuh vagina & Kebersihan vagina & $1(0,9)$ & $105(99,1)$ \\
\hline & & Sikap mencuci tangan & $13(12,3)$ & $93(87,7)$ \\
\hline & & Cara membasuh vagina & $0(0)$ & $106(100)$ \\
\hline & & Guna membasuh vagina & $5(4,7)$ & $101(95,3)$ \\
\hline & & Air yang digunakan saat membasuh & $0(0)$ & $106(100)$ \\
\hline & & Mengeringkan vagina & $6(5,7)$ & $100(94,3)$ \\
\hline & & Penggunaan cairan antiseptik & $22(20,8)$ & $84(79,2)$ \\
\hline \multirow[t]{7}{*}{2} & Pencegahan keputihan & Pembalut saat menstruasi & $0(0)$ & $106(100)$ \\
\hline & & Bahan celana dalam & $10(9,4)$ & $96(90,6)$ \\
\hline & & Frekuensi mengganti & $1(0,9)$ & $105(99,1)$ \\
\hline & & Pakaian dalam lembab & $7(6,6)$ & $99(93,4)$ \\
\hline & & Penggunaan pantyliner & $9(8,5)$ & $97(91,5)$ \\
\hline & & Pemilihan pantyliner & $5(4,7)$ & $101(95,3)$ \\
\hline & & Mencukur rambut pubis & $31(29,2)$ & $75(70,8)$ \\
\hline
\end{tabular}

Tabel 3 Tipe Pertanyaan dan Tingkat Perilaku Vaginal Hygiene

\begin{tabular}{|c|c|c|c|c|}
\hline \multirow[b]{3}{*}{ No } & \multirow[b]{3}{*}{ Tipe Pertanyaan } & \multirow[b]{3}{*}{ Nomer dan konten } & \multicolumn{2}{|c|}{ Hasil } \\
\hline & & & Tidak & Ya \\
\hline & & & $\%$ & $\%$ \\
\hline \multirow[t]{6}{*}{1} & Kebiasaan mencuci vagina & Mencucui tangan & $0(0)$ & $106(100)$ \\
\hline & & Sumber air & $2(1,9)$ & $104(98,1)$ \\
\hline & & Kebiasaan membersihkan & $15(14.2)$ & $91(85,8)$ \\
\hline & & Kebiasaan menggunakan cairan antiseptik & $8(7,5)$ & $98(92,5)$ \\
\hline & & Kebiasaan menggunakan pengharum & $36(34)$ & $70(66)$ \\
\hline & & Kebiasaan mengeringkan daerah kewanitaan & $8(7,5)$ & $98(92,5)$ \\
\hline \multirow[t]{5}{*}{2} & Penggunaan pembalut & Kebiasaan menggunakan pembalut & $0(0)$ & $106(100)$ \\
\hline & & Kebiasaan mengganti pembalut & $0(0)$ & $106(100)$ \\
\hline & & (11) Penggunaan pentyliner & $21(19,8)$ & $85(80,2)$ \\
\hline & & (12) Frekuensi penggunaan pantyliner & $21(19,8)$ & $85(80,2)$ \\
\hline & & (13) Jumlah pentyliner & $24(22,6)$ & $82(77,4)$ \\
\hline \multirow[t]{2}{*}{3} & Penggunaan pakaian dalam & Mengganti pakaian dalam & $0(0)$ & $106(100)$ \\
\hline & & Bahan pembuat celana dalam & $11(10,4)$ & $95(89,6)$ \\
\hline \multirow[t]{2}{*}{4} & Mencukur rambut kemaluan & (14) Kebiasaan mencukur & $29(27,4)$ & $77(72,6)$ \\
\hline & & Frekuensi mencukur & $32(30,2)$ & $74(69,8)$ \\
\hline \multirow[t]{2}{*}{5} & Keputihan & Waktu keputihan & $2(1,9)$ & $104(98,1)$ \\
\hline & & Riwayat keputihan patologis & $32(30,2)$ & $74(69,8)$ \\
\hline
\end{tabular}

Pengetahuan seseorang terhadap suatu objek dapat memiliki tingkat persepsi yang berbeda-beda. Hal tersebut dipengaruhi oleh beberapa faktor yaitu faktor usia, pendidikan, dan lingkungan. Pendidikan sebagai salah satu kunci luasnya pengetahuan yang dimiliki oleh seseorang.
Semakin tinggi pendidikan, maka akan semakin tinggi pengetahuan yang dimiliki oleh seseorang. Selain itu, pengalaman juga menjadi hal yang penting dalam menambah pengetahuan seseorang. Responden yang digunakan dalam penelitian ini termasuk dalam kategori remaja menengah (14-16 
tahun) dan remaja akhir (17-20 tahun). Pada fase ini rasa ingin tahu remaja cenderung meningkat akan suatu hal. Selain itu, pada fase ini pola pikir seorang remaja akan mengalami proses perubahan menuju dewasa dan menjadi lebih matang dalam bertindak. $^{7}$

Hasil penelitian ini tidak sesuai dengan penelitian yang dilakukan oleh Tranggono pada tahun 2017 tentang gambaran pengetahuan, sikap, dan perilaku menjaga kebersihan organ genitalia eksterna terhadap kejadian keputihan abnormal pada siswi Mts. Al-Gaotsiyah Jakarta Barat. Penelitian tersebut menggunakan 120 responden dan terdapat 92 responden yang memiliki pengetahuan buruk (76,7\%). ${ }^{8}$ Namun, hasil penelitian tersebut sesuai dengan penelitian yang dilakukan oleh Rakhmilla pada tahun 2016 dengan judul Knowledge, Attitude, and Practice about Vaginal Discharge on School-Age Girls in Jatinangor Senior High School. Pada penelitian tersebut didapatkan tingkat pengetahuan responden dikategorikan buruk $(49,1 \%){ }^{9}$

Pada penelitian yang dilakukan oleh Tranggono pada tahun 2017 responden yang digunakan adalah siswi Sekolah Menengah Pertama Mts. Al-Gaotsiyah Jakarta Barat dimana usia responden yang digunakan adalah 12-16 tahun. ${ }^{8} \mathrm{Hal}$ ini mempengaruhi hasil penelitian yang dilakukan. Usia tersebut termasuk dalam kategori remaja awal (10-13 tahun) dan remaja menengah (14-16 tahun). Pada fase remaja awal remaja baru mengembangkan pola pikirnya, dan pengalaman yang didapatkan oleh responden masih belum banyak untuk dapat menambah pengetahuannya mengenai vaginal hygiene. ${ }^{7}$

Lingkungan juga merupakan faktor yang penting dalam menambah pengetahuan. Lingkungan dapat berupa lingkungan sekitar rumah, keluarga, dan sekolah. Pengetahuan mengenai vaginal hygiene umumnya dapat diberikan oleh orang tua atau kerabat terdekat. Namun, pengetahuan yang dimiliki oleh orang tua juga dapat dipengaruhi oleh faktor pengalaman dan pendidikan. Hasil dari penelitian ini menunjukkan $89,6 \%$ responden mendapatkan informasi mengenai vaginal hygiene dari orangtua. Sedangkan pada penelitian yang dilakukan oleh Rakhmilla pada tahun 2016 menyebutkan bahwa $62,7 \%$ orangtua dari responden bekerja sebagai pedagang dan $17,8 \%$ sebagai buruh. ${ }^{9}$ Hal tersebut tentu mempengaruhi hasil penelitian yang dilakukan. Pekerjaan orangtua responden tersebut banyak dilakukan diluar rumah dan intensitas orangtua untuk bertemu dengan anaknya minim, sehingga kurangnya waktu bagi orang tua untuk mengedukasi responden mengenai vaginal hygiene. Selain waktu, rendahnya pendidikan dari orangtua juga dapat mempengaruhi minimnya kualitas edukasi yang diberikan kepada responden mengenai vaginal hygiene.

\section{Sikap tentang Vaginal Hygiene dalam Pencegahan Keputihan}

Berdasarkan hasil penelitian yang telah dilakukan, didapatkan sikap responden adalah baik (100\%). 106 responden (100\%) memiliki sikap yang baik mengenai cara membasuh vagina. Sikap 78 orang dari 106 responden $(90,6 \%)$ tentang pemilihan bahan pakaian dalam adalah baik. Hasil penelitian mengenai sikap dapat dilihat pada tabel 2 .

Sikap adalah reaksi atau respon seseorang yang masih tertutup terhadap stimulus atau objek. Sikap tersebut juga merupakan gambaran atau refleksi yang akan dilakukan remaja tersebut. Stimulus atau objek tersebut dapat berupa pengetahuan. ${ }^{10}$ Setelah seseorang mendapat informasi, informasi tersebut akan diterima, diolah, dan di respon. Selain itu, seseorang juga dapat membedakan hal-hal yang dapat berdampak baik dan buruk bagi dirinya. ${ }^{11}$ Melalui pengetahuan yang dimiliki, seseorang dapat mengetahui bahwa menjaga vaginal hygiene adalah hal positif yang harus dilakukan untuk mencegah keputihan. Maka setelah menyikapi informasi tersebut, responden akan menerapkan perilaku menurut pengetahuan yang dimiliki.

Hasil penelitian ini tidak sesuai dengan penelitian yang dilakukan oleh Tranggono pada tahun 2017, dimana pada penelitiannya dari 120 responden tercatat 75 responden di kategorikan buruk $(62,5 \%) .{ }^{8}$ Namun, penelitian tersebut tidak sesuai dengan penelitian yang dilakukan oleh Rakhmilla pada tahun 2016, dimana didapatkan hasil sikap adalah baik mendekati buruk $(58,20 \%) .{ }^{9}$

Perbedaan hasil penelitian yang telah dilakukan disebabkan oleh perbedaan tingkat pengetahuan yang dimiliki oleh tiap responden. Kurangnya pengetahuan yang dimiliki menyebabkan minimnya informasi yang dapat di terima, diolah dan direspon oleh responden. Sehingga, responden tidak mengetahui mana hal yang baik dan buruk bagi dirinya. Seperti banyaknya informasi media seperti televisi, majalah, dan surat kabar mengenai iklan pembersih untuk alat genital. Iklan yang menarik dapat membuat remaja untuk mencoba dan dengan kurangnya pengetahuan mereka tidak mempertimbangkan dampak baik dan buruknya. Ketidaktahuan tersebut akan mengakibatkan responden berpikir bahwa semua informasi yang diterima di media adalah benar dan baik bagi kesehatannya. Selain itu kurangnya pengetahuan juga dapat menyebabkan responden berpikir keputihan adalah hal yang wajar pada tiap perempuan dan semua keputihan yang dialami adalah sama. Kurangnya motivasi responden untuk mencari tahu mengenai vaginal hygiene juga dapat 
mempengaruhi hasil dari sikap responden. Bila tidak diatasi dengan baik, keputihan dapat menimbulkan penyakit seperti kanker serviks, kemandulan, dan kehamilan diluar uterus.

\section{Perilaku tentang Vaginal Hygiene dalam Pencegahan Keputihan}

Berdasarkan penelitian yang telah dilakukan didapatkan hasil perilaku vaginal hygiene dalam mencegah keputihan patologis secara umum adalah baik $(98,2 \%)$. Namun, masih ditemukan beberapa perilaku yang buruk yaitu 98 orang dari 106 responden (92,5\%) masih menggunakan cairan antiseptik pada daerah genitalnya dan 70 orang dari 106 responden (66\%) masih menggunakan pengharum. Hasil penelitian mengenai perilaku dapat dilihat pada tabel 3.

Perilaku adalah suatu kegiatan atau aktifitas yang dipengaruhi oleh perhatian, pengamatan, pikiran, ingatan, dan fantasi. Penerimaan perilaku baru disadari oleh pengetahuan, kesadaran, dan sikap yang positif. Perilaku juga didefinisikan sebagai respon atau reaksi seseorang terhadap stimulus. Pembentukan perilaku dapat dipengaruhi oleh tiga faktor yaitu faktor mempermudah (sikap, pengetahuan, konsep diri, nilai dan informasi), faktor pendukung (sarana, prasarana, keahlian dan ketrampilan), dan faktor pendorong (perilaku dan sikap dari orang lain atau lingkungan sekitarnya). ${ }^{7}$

Berdasarkan penelitian yang telah dilakukan didapatkan hasil perilaku vaginal hygiene dalam mencegah keputihan patologis adalah baik $(98,2 \%)$. Hasil penelitian ini tidak sesuai dengan penelitian yang dilakukan oleh Tranggono pada tahun 2017 dimana didapatkan hasil perilaku vaginal hygeiene dalam pencegahan keputihan adalah buruk (70\%). ${ }^{8}$ Penelitian Tranggono (2017) tidak sesuai dengan penelitian yang dilakukan oleh Rakhmilla pada tahun 2016, dimana didapatkan hasil perilaku vaginal hygeiene dalam pencegahan keputihan adalah baik mendekati buruk (55.80\%). ${ }^{9}$

Perbedaan hasil tersebut dikarenakan perbedaan tingkat pengetahuan pada tiap responden. Semakin tinggi pengetahuan seseorang, maka semakin mudah seseorang untuk menyikapi informasi-informasi yang diterima. informasi yang diterima oleh seseorang akan diterima, diolah, dan di respon sehingga seseorang dapat benar-benar mengerti mengenai informasi yang diberikan dan dapat mengelompokkan hal baik dan buruk bagi dirinya. Selanjutnya, informasi yang dianggap baik akan diwujudkan dalam kehidupan sehari-hari melalui perilaku. Selain itu, pengetahuan juga merupakan faktor mempermudah yang dapat mempengaruhi perilaku dari seseorang.
Pada penelitian ini ditemukan angka penggunakan cairan antiseptik dan pengharum pada daerah genitalnya masih tinggi yaitu $92,5 \%$ dan $66 \%$. Penggunaan cairan antiseptik dan pengharum dapat membunuh flora normal yang ada di vagina. Flora normal yang ada di vagina berperan penting dalam menjaga $\mathrm{pH}$ vagina agar tetap dalam kondisi normal. Keadaan $\mathrm{pH}$ yang normal akan membunuh bakteri patogen yang ada di vagina, dimana bakteri patogen tersebut merupakan salah satu penyebab keputihan. Namun bila terjadi gangguan keseimbangan flora normal akibat pengunaan cairan antiseptik, maka akan terjadi perubahan $\mathrm{pH}$ yang akan memicu kolonisasi bakteri patogen. Bakteri patogen tersebut dapat menyebabkan vaginosis bakterial, vaginitis, dan cervitis sehingga sekret yang dikeluarkan vagina menjadi tidak normal. ${ }^{12,13}$

Hasil yang buruk pada beberapa hal tersebut menunjukkan bahwa responden mengetahui pengetahuan tentang vaginal hygiene dengan baik namun beberapa hal belum dapat dipraktekkan dengan baik. Hal tersebut dapat terjadi karena kurangnya motivasi untuk mempraktekkan pengetahuan yang diketahui oleh responden. Selain itu ada ketertarikan dari responden untuk mencoba produk- produk yang diiklankan di media, namun responden belum berpikir panjang mengenai dampak negatif yang akan ditimbulkan bila produk tersebut digunakan dalam jangka panjang.

\section{Keterbatasan Dalam Penelitian}

Penelitian ini hanya merupakan penelitian deskriptif yang tidak bisa menghubungkan tingkat pengetahuan, sikap, dan perilaku mengenai vaginal hygiene terhadap kejadian keputihan patologis.

Pada penelitian ini didapatkan masih banyaknya responden yang menggunakan cairan antiseptik maupun sabun pada daerah genitalnya, namun pada kuesioner responden tidak menuliskan merk sabun maupun cairan antiseptik yang digunakan. Padahal hal ini penting dan dapat dijadikan bahan untuk mengedukasi remaja nantinya.

\section{SIMPULAN}

Berdasarkan penelitian yang telah dilakukan didapatkan hasil tingkat pengetahuan responden mengenai vaginal hygiene terhadap kejadian keputihan patologis adalah baik yaitu sebesar 99,9\%. Tingkat sikap responden mengenai vaginal hygiene terhadap kejadian keputihan patologis adalah baik yaitu sebesar $100 \%$. Tingkat perilaku responden mengenai vaginal hygiene terhadap kejadian keputihan patologis adalah baik yaitu sebesar $98,2 \%$. 


\section{DAFTAR PUSTAKA}

1. Adjie S. Kesehatan Reproduksi Remaja Dalam Aspek Sosial. Indonesian Pediatric Society Article; 2013 [diakses: 7 September 2017]. Tersedia pada: http://www.idai.or.id/ artikel/seoutar-kesehatananak/kesehatan-reproduksiremaja-dalam-asp ek-sosial

2. Manuaba IBG. Alat Reproduksi Wanita. Dalam: Ester M, Chuliana L, editor. Memahami Kesehatan Reproduksi Perempuan. Jakarta: EGC; 2009. h. 61-63.

3. Prasetyowati. Hubungan Personal Hygiene dengan Kejadian Keputihan Pada Siswi SMU Muhamadiyah 1 Metro. Jurnal Kesehatan. 2009;11:14-18.

4. Eckert LO, Lentz GM. Infections Of The Lower Genital Tract. In: Lentz GM, Lobo RA, Gershenson DM, editors. Comprehensive Gynecology. $6^{\text {th }}$ ed. Philadelphia: Elsevier Mosby; 2012. p. 24-28.

5. Nurhadini S, Zainal E, Efrina D. Hubungan Personal Hygiene dengan Keputihan Pada Perempuan Usia Subur di Wilayah Kerja Puskesmas Lingkar Timur. Jurnal Ilmiah Kedokteran. 2012;2(3):12-16.

6. Kementerian Kesehatan Republik Indonesia. Situasi Kesehatan Reproduksi Remaja. Ministry Of Health Republic Of Indonesia Article. Kemenkes RI; 2015 [diakses: 7 September 2017]. Tersedia pada: http://www. depkes.go.id/resource/download/pusdatin/infodatin $\% 20$ reproduksi\%20remaja-ed.pdf

7. Notoatmodjo S. Ilmu Perilaku kesehatan. Jakarta: Rineka Cipta; 2010. p. 22-18.
8. Tranggono YA, Winata SD, Kertadjaya W. Gambaran Pengetahuan, Sikap, dan Perilaku Menjaga Kebersihan Organ Genitalia Eksterna terhadap Kejadian Keputihan Abnormal pada Siswi Mts. Al-Gaotsiyah, Jakarta Barat. Jurnal Kedokteran Meditek. 2017;4(2):14-19.

9. Rakhmilla LE, Fah LI, Sofiatin Y, Widjadjakusuma A, Rosyada NA. Knowledge, Attitude, and Practice about Vaginal Discharge on School- Age Girls in Jatinangor Senior High School. Open Access Library Journal. 2016;3(1):19-22.

10. Qomariyah SN, Umah K, Fitriana I. Hubungan Pengetahuan dan Sikap tentang Kebersihan Genitalia dengan Kejadian Fluor Albus (Keputihan) pada Remaja Putri. JNC. 2012;3(6):30-40.

11. Suparman MA. Desain Instruksional Modern: Panduan Para Pengajar \& Inovator Pendidikan. Jakarta: Erlangga; 2012. p. 34-38

12. Sherrard, Jackie, Ison, Cathy, Judith M, Emma W, Janet W, Ann S. United Kingdom National Guidline on the Management of Trichomonas vaginalis. International Journal of STD and AIDS. 2014;25(8):541-549.

13. Monaidi SW, Linuwih S. Ilmu Penyakit Kulit dan Kelamin. Jakarta: Badan Penerbit FKUI; 2015. p. 38-44.

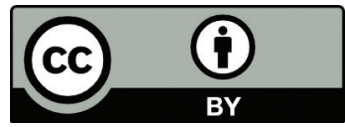

This work is licensed under a Creative Commons Attribution 